\title{
Modeling of groundwater flow for Mujib aquifer, Jordan
}

\author{
FAyez Abdulla ${ }^{1, *}$ and Tamer Al-Assa'D ${ }^{2}$ \\ ${ }^{1}$ Associate Professor of Water Resources, Civil Engineering Department, Jordan University \\ of Science \& Technology, P.O Box 3030, Irbid 22110, Jordan. \\ ${ }^{2}$ Water Resources Consultant, Eco-Consult, Amman, Jordan. \\ *e-mail: fabdulla@just.edu.jo
}

Jordan is an arid country with very limited water resources. Groundwater is the main source for its water supply. Mujib aquifer is located in the central part of Jordan and is a major source of drinking water for Amman, Madaba and Karak cities. High abstraction rates from Mujib aquifer during the previous years lead to a major decline in water levels and deterioration in groundwater quality. Therefore, proper groundwater management of Mujib aquifer is necessary; and groundwater flow modeling is essential for proper management. For this purpose, Modflow was used to build a groundwater flow model to simulate the behavior of the flow system under different stresses. The model was calibrated for steady state condition by matching observed and simulated initial head counter lines. Drawdown data for the period 1985-1995 were used to calibrate the transient model by matching simulated drawdown with the observed one. Then, the transient model was validated by using drawdown data for the period 1996-2002. The results of the calibrated model showed that the horizontal hydraulic conductivity of the B2/A7 aquifer ranges between 0.001 and $40 \mathrm{~m} / \mathrm{d}$. Calibrated specific yield ranges from 0.0001 to 0.15 . The water balance for the steady state condition of Mujib aquifer indicated that the total annual direct recharge is $20.4 \times 10^{6} \mathrm{~m}^{3}$, the total annual inflow is $13.0 \times 10^{6} \mathrm{~m}^{3}$, springs discharge is $15.3 \times 10^{6} \mathrm{~m}^{3}$, and total annual outflow is $18.7 \times 10^{6} \mathrm{~m}^{3}$. Different scenarios were considered to predict aquifer system response under different conditions. The results of the sensitivity analysis show that the model is highly sensitive to horizontal hydraulic conductivity and anisotropy and with lower level to the recharge rates. Also the model is sensitive to specific yield.

\section{Introduction}

Jordan is one of the poorest countries of the world in terms of water resources. About $91 \%$ of its area has rainfall less than $200 \mathrm{~mm}$ per year. Most of it is thus desert land. Groundwater contributes a significant portion of the water supply in Jordan. Increased dependence on groundwater needs improved aquifer management with respect to understanding recharge and discharge issues, planning rates of withdrawal, and balancing demands of multiple water users (Tompson et al 1999).

The rainfall in Jordan is the main source of water recharge for surface and subsurface water resources. It is relatively scarce and varies considerably with location due to the variable topographic features and climatic conditions. This makes Jordan suffer from limited water resources. Further more, due to the increasing demand, the withdrawal from these aquifers is almost double that of the safe yield. This will eventually lead to the depletion of water resources and deterioration in the water quality (National Water Master Plan, 2001).

By using Modflow computer code, this work presents a mathematical model for the study area for predicting, with reasonable accuracy, the response of Mujib aquifer to different scenarios of

Keywords. Modflow; Mujib basin-Jordan; groundwater modeling; calibration; validation. 


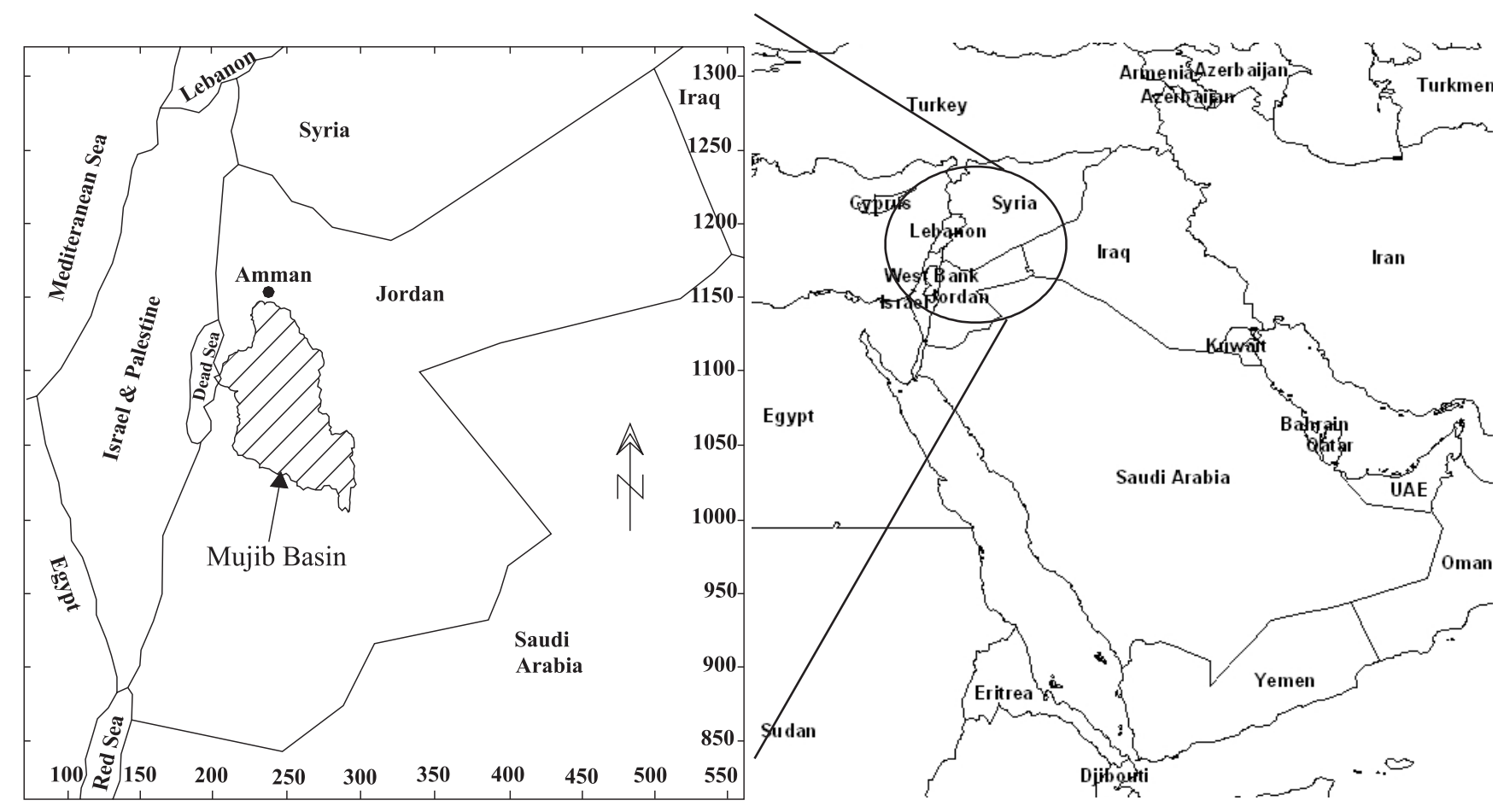

Figure 1. Study area location (after JICA/WAJ 1987).

future abstractions. The model may, in future, help decision makers and planners in selecting optimum management schemes suitable for arid and semiarid regions.

\section{Methodology}

The methodology followed in this research can be summarized as follows:

- Collection of data, which includes the physical parameters such as hydraulic conductivity, aquifer thickness, recharge, and pumping rates. Geological boundary, distribution of geologic formation, topographic maps and maps show, groundwater flow directions.

- Identification of the geological and hydrological setting of the study area.

- Dividing the study area into a grid mesh. The size of the grids was irregular, depending upon the location and density of the wells and the gradient of the water table. The Modflow (Chiang and Kinzelbach 1998) was applied to simulate three-dimensional groundwater flow for the study area.

- Estimation of the model parameters by manual adjusting until a good match between computed and observed water levels is obtained.

- Statistical analysis of the calibration results.

- Conducting sensitivity analysis to test the effect of uncertainty in aquifer parameters and boundary and initial conditions on the model outputs.

- Verification of the model results with the observed data.

- Analysis of different scenarios which includes future stresses such as groundwater recharge rates and pumping based on projected demands.

\section{Study area}

The study area lies in the central part of Jordan as shown in figure 1 . The area of Mujib watershed is about $5760 \mathrm{~km}^{2}$. It consists of two major catchment areas: Wadi Mujib catchment (about $3660 \mathrm{~km}^{2}$ ), and Wadi Wala catchment (about $2100 \mathrm{~km}^{2}$ ). It is bounded westward by the Dead Sea catchment, northward by the Zarqa basin, eastward by Azraq basin, and southward by Jafr basin.

\section{Hydrogeology of Mujib basin}

Figure 2 shows the hydrogeological framework of the Mujib basin. Four aquifer systems were recognized in Mujib basin: B2/A7, A4, A2, and Kurnub. The B2/A7 aquifer has been considered to be a uniform aquifer unit with hydraulic connections, which is widespread throughout the study area with a thickness of 100 to $300 \mathrm{~m}$. The $\mathrm{B} 2 / \mathrm{A} 7$ formation is an excellent aquifer with high 


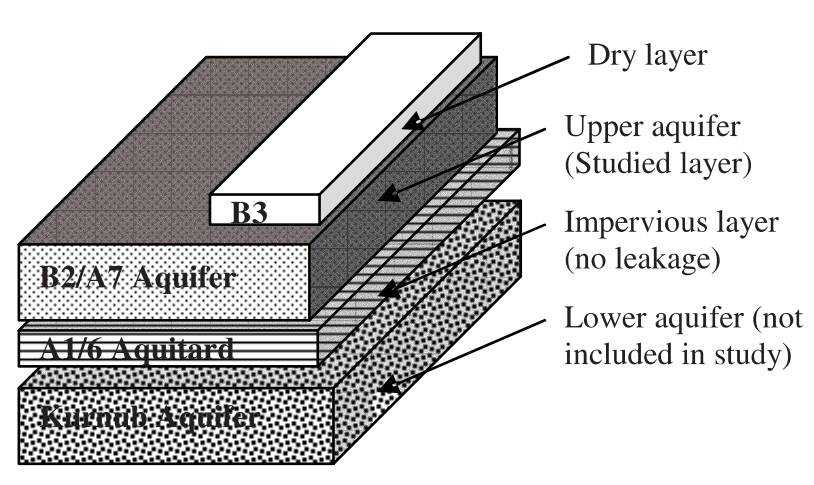

Figure 2. Conceptual model of the study area.

permeability due to joints, fractures and karstification of the limestone (JICA/WAJ 1987). The B2/A7 aquifer is outcropped in the western and central parts of the Mujib basin, and is overlaid by the B3 aquiclude in the eastern part. The B3 aquiclude is dry over the Mujib basin and it is also overlaid by $\mathrm{B} 4 / 5$ aquifer in the northeastern part of Mujib, which is also dry. So, natural recharge almost occurred in the western and central parts of Mujib basin while a small quantity of precipitation could recharge in the eastern part of the basin.

The B2/A7 aquifer and Kurnub aquifer are separated by the A1/6 Aquitard. The only abstractions until recently are from the B2/A7 aquifer. Kurnub aquifer is not utilized because it is deep in most parts. So the study will be performed only on the B2/A7 aquifer. Another reason for excluding the Kurnub aquifer is the absence of any observation well for this aquifer.

The water table elevation of the B2/A7 layer is lower than the base elevation of the B3 layer, and so the B2/A7 is considered as an unconfined aquifer. The depth of water in the Mujib basin varies from less than $10 \mathrm{~m}$ to more than $300 \mathrm{~m}$. The A1/6 Aquitard is considered as an impervious layer in the model.

\section{Model application}

The model domain was selected to cover $5760 \mathrm{~km}^{2}$ of the Mujib watershed. The domain is located between 215000 PGE, 20000 PGN (left lower corner) and 298000 PGE, 148000 PGN (upper right corner) according to the Palestinian coordinate. The model domain was discretized using 129 rows $\times 99$ columns rectangular cells. This discretization produces 12771 cells in the model layer. The width of the cells along rows (in x-direction varies between 250 and $2000 \mathrm{~m}$ and along columns (in y-direction varies between 250 and $4000 \mathrm{~m}$ depending on the location and concentration of wells and springs.

\section{Input parameters}

Topographical and hydrogeological contour maps were used to determine the top and bottom of the B2/A7 layer for each cell. The B2/A7 aquifer system has a wide range of hydraulic conductivities due to karst features, enlarged joints, sink holes, caves and solution breccias that developed in and around the fault zones. The measured transmissivity from the pumping tests provide values ranging from 5 to $26,000 \mathrm{~m}^{2} / \mathrm{d}$ (JICA/WAJ 1987). The high transmissivities are located along the zone of major Wadi system in the Wala basin and in the Mujib basin. The hydraulic conductivity values of the study area varies in the range of $1.0 \times 10^{-8}$ to $5.0 \times 10^{-3} \mathrm{~m} / \mathrm{s}$. The bulk of the conductivity values obtained from pumping tests lies between $1.0 \times 10^{-6}$ and $1.0 \times 10^{-4} \mathrm{~m} / \mathrm{s} \quad(B G R / C W A J$ 1987).

Fourteen springs exist in the Mujib basin, which are grouped into five groups. Most of these are located in the valley's outcrop areas in the Wadi Wala, Wadi Heidan, and Wadi Mujib. The largest group of springs that discharges regional flow from the B2/A7 aquifer is located in the Wadi Heidan with an annual average discharge of $15.3 \times 10^{6} \mathrm{~m}^{3}$.

The amount of groundwater extraction had increased since the 1970s due to more development that occurred in Jordan as well as in the Mujib region. The overall abstraction was assumed to be around $5.2 \times 10^{6} \mathrm{~m}^{3} / \mathrm{y}$, for the period between 1976 and 1979 , and around $10.8 \times 10^{6} \mathrm{~m}^{3} / \mathrm{y}$, for the period between 1980 and 1984. Starting from 1985 new groundwater wells had been drilled in order to provide water to Amman. The abstraction rates reached about $29.5 \times 10^{6} \mathrm{~m}^{3}$ based on the measured abstraction quantities. Also another jump occurred in 1993 when more wells were drilled to supply water to Amman, Madaba and Karak. The abstraction rates recorded about $55.5 \times 10^{6} \mathrm{~m}^{3}$. Currently more than 350 wells are annually abstracting about $58 \times 10^{6} \mathrm{~m}^{3}$ of water.

\section{Boundary and initial conditions}

Depending on the groundwater flow pattern of the B2/A7 aquifer and the locations of the groundwater wells, location and the type of the boundary conditions for the Mujib basin are proposed as shown in figure 3 . The numbers in it refer to the site specification:

1. Amman mountains in the north side are considered as a physical boundary (recharge side) defined as a constant head boundary, where flow comes from this side; 


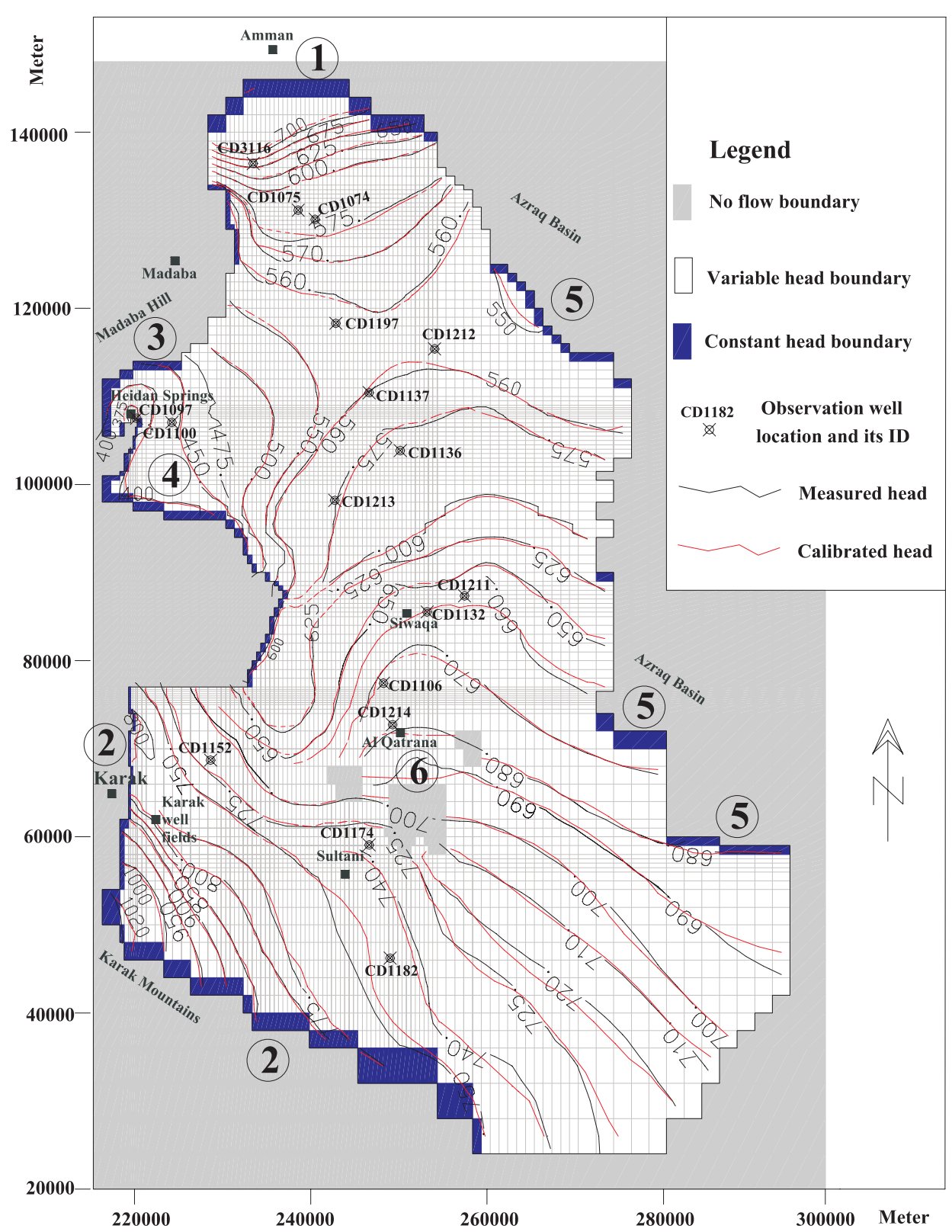

Figure 3. Flow model boundaries, grid, and the measured and simulated water levels for Mujib basin (B2/A7 aquifer).

2. The southwestern side is also defined as a constant head boundary where flow comes from Karak mountains which is considered as a recharge area to the Mujib basin;

3. Another important recharge side to the Mujib basin is in the northwestern side above the Heidan springs, where flow comes from Madaba hills, is also defined as a constant head boundary;

4. The middle western part of the Mujib basin around Wadi Wala and Wadi Mujib is considered as a constant head boundary as groundwater flows out towards these Wadis;

5. Northeastern side and lower middle eastern side of the Mujib basin are also major outflow boundaries towards Azraq basin, where they are defined as a constant head boundary;

6. Inactive cells are assigned to the area beyond Qatrana city where no water exists in the B2/A7 aquifer.

The proposed boundary conditions for points 1 to 5 are assumed to be constant head because these boundaries are far enough from the abstraction wells which will not significantly affect the water level at these boundaries.

Figure 3 shows the water level map for Mujib basin created in 1984 from the initial water level in the wells during the seventies when the extraction quantities were still minor. This represents the initial head distribution for Mujib basin. 


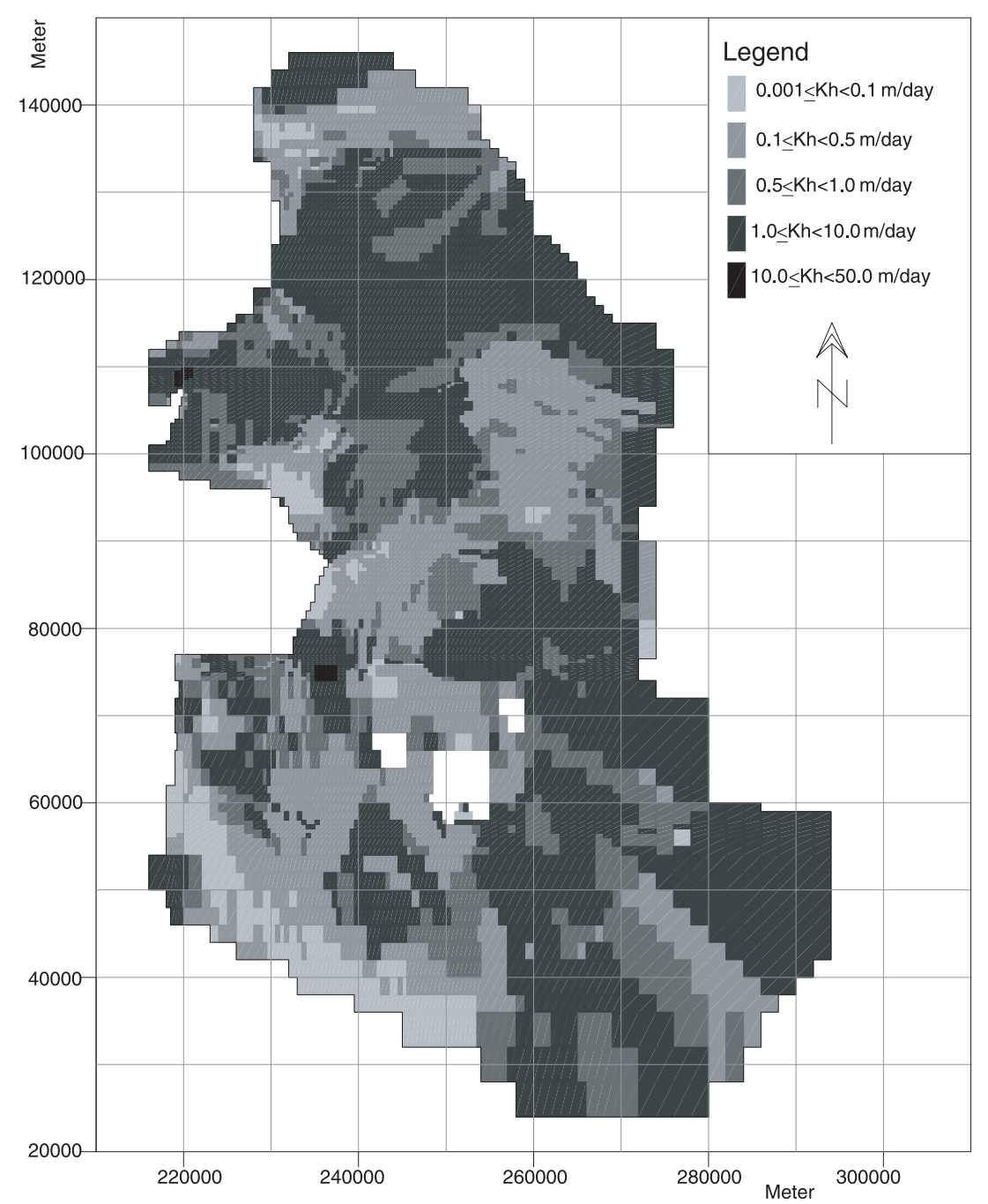

Figure 4. Map of the calibrated horizontal hydraulic conductivity of the B2/A7 aquifer system.

\section{Steady state calibration}

The steady state condition is a condition that existed in the aquifer before any development had occurred. Matching the initial heads observed for the aquifer with the hydraulic heads simulated by Modflow is called steady state calibration. It is done by sequential adjustment of the model parameters.

Hydraulic conductivities estimated from previous studies and from pumping tests were used as initial values for the steady state simulation. By trial and error calibration, the horizontal hydraulic conductivity was adjusted during many sequential model runs until the match between the observed and simulated heads were obtained. Also minor adjustments were done on the boundary conditions that were firstly used in the initial runs. A comparison of measured and simulated water level contours of the B2/A7 aquifer is presented in figure 3 . It is clearly shown that there is a good agreement between the simulated and measured heads. The distribution of the values of the calibrated horizontal hydraulic conductivity is shown in figure 4. Most values of the hydraulic conductivity are ranged between $0.1 \mathrm{~m} / \mathrm{d}$ and $3 \mathrm{~m} / \mathrm{d}$. The maximum value of the calibrated hydraulic conductivity occurred around Heidan springs where it reached $40 \mathrm{~m} / \mathrm{d}$, while the minimum value reached $0.001 \mathrm{~m} / \mathrm{d}$ to the east of Wadi Mujib. As the simulation was done on one layer with an impermeable bottom, no vertical hydraulic conductivity is required to be calibrated. The presence of Siwaqa Fault creates sharp changes in the hydraulic conductivity in some areas between its sides along the path.

Figure 5 shows the water balance for the B2/A7 aquifer system in Mujib basin at steady state condition with a discrepancy of $-1.91 \%$ where the calibrated outflow exceeded the inflow by $0.64 \times 10^{6} \mathrm{~m}^{3}$. The major inflows come from Amman mountains at the north of Mujib basin which is indicated by number (1) in figure 3 with about $4.1 \times 10^{6} \mathrm{~m}^{3}$, and from Madaba hills 


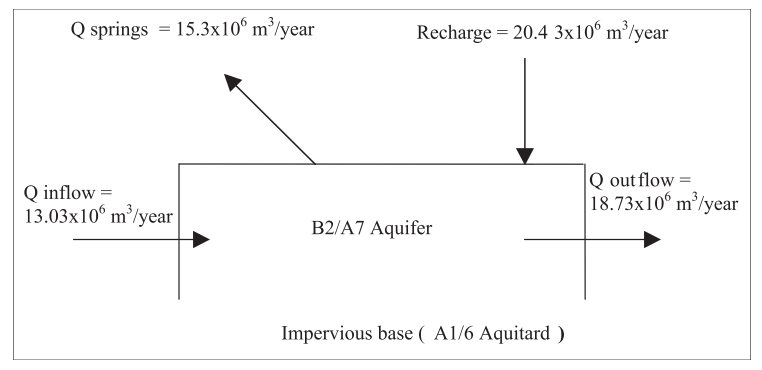

Figure 5. Water balance of the model domain at the steady state conditions (units in $10^{6} \mathrm{~m}^{3} /$ year).

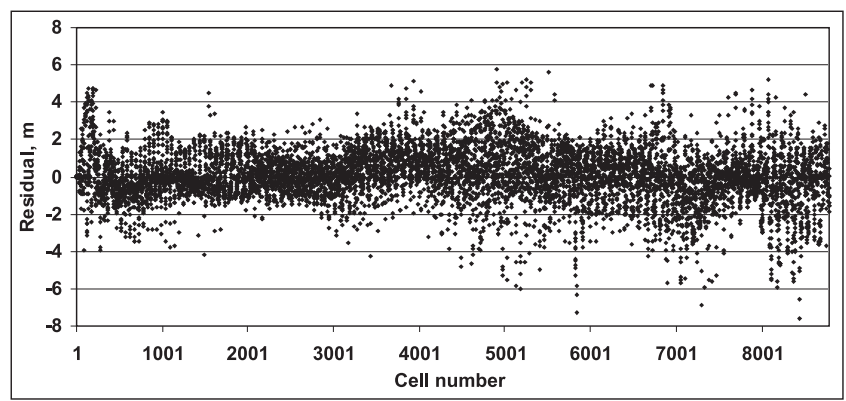

Figure 6. Plot of residual heads of model cells.

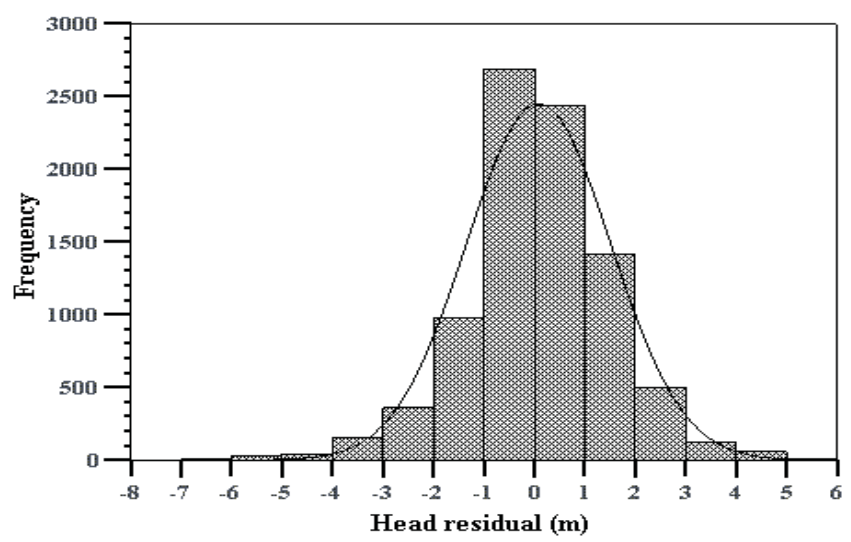

Figure 7. Histogram of residual heads (observed minus calibrated).

(indicated by number (3)) with about $5.2 \times 10^{6} \mathrm{~m}^{3}$ and also from Karak mountains (indicated by number $(2)$ ) with about $3.5 \times 10^{6} \mathrm{~m}^{3}$. The major outflows from the B2/A7 aquifer system are toward Wadi Mujib and Wala (indicated by number (4)), and towards Azraq basin (indicated by number (5)) with about 9.3 and $7.6 \times 10^{6} \mathrm{~m}^{3}$ respectively, in addition to the spring discharge equal to about $15.3 \times 10^{6} \mathrm{~m}^{3}$.

\section{Model evaluation}

Contour maps of measured and simulated heads (figure 3) provide a visual, qualitative measure of the similarity between patterns, but they also include errors introduced by contouring and therefore should not be used as the only proof of calibration. A scatter plot of residual heads of model cells as shown in figure 6 is another way of showing the calibration fit. There is a balanced distribution of residuals around zero and most of the residual heads are located between $2 \mathrm{~m}$ and $-2 \mathrm{~m}$. A histogram is also shown in figure 7 for the residual heads between observed and simulated heads for all active cells in the model. It is clear that the distribution of the histogram is almost normal around zero with an average residual of $0.08 \mathrm{~m}$, where ideally it should be zero.

\section{Transient calibration}

Successful transient calibration depends mainly on the good estimation of hydraulic conductivities and boundary conditions obtained from the steady state calibration. Generally, specific yield for unconfined aquifers and storage coefficient for confined aquifers are the main parameters that are changed during the transient calibration. In this study, specific yield will be evaluated as the B2/A7 aquifer system in the Mujib basin is unconfined. The variations in the natural recharge quantities due to the rainfall fluctuation are taken into consideration during the transient calibration period.

The year of 1976 was considered as the year in which significant water production began. One stress period from year 1976 until 1979 with 48 time steps and constant wells discharge of $5.2 \times 10^{6} \mathrm{~m}^{3} /$ year was considered. Another stress period from 1980 until 1984 with 60 time steps and constant wells discharge of $10.8 \times 10^{6} \mathrm{~m}^{3}$ year was considered. The natural recharge during 1976 and 1984 is assumed to be constant and equal to the average annual natural recharge due to the lack in water levels data during this period. The period from year 1985 until year 2002 was divided into 36 stress periods, in which each year was split into two stress periods, so that the natural recharge only occurred in the first one and its length was 152 days (5 months), while no recharge occurred in the second stress period with a length of 213 days ( 7 months). It is assumed that wells discharge have the same rates over the year. Figure 8 shows the monthly distribution of the natural recharge and wells abstraction quantities during the transient period.

The transient-state model was calibrated using available water-level data from 2 wells for the period 1985-1995, while the remaining part (19962002 ) is left for the validation process. These wells were selected because of the sufficient water-level records. 


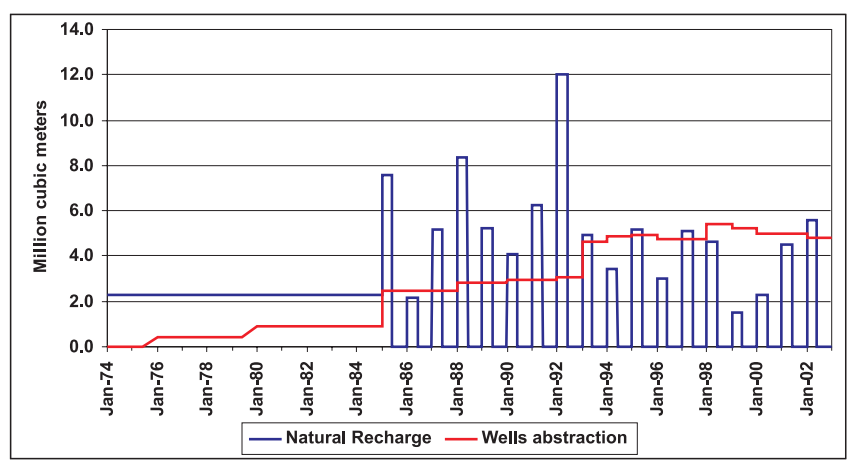

Figure 8. Distribution of the monthly natural recharge and wells abstraction quantities during the simulation period.
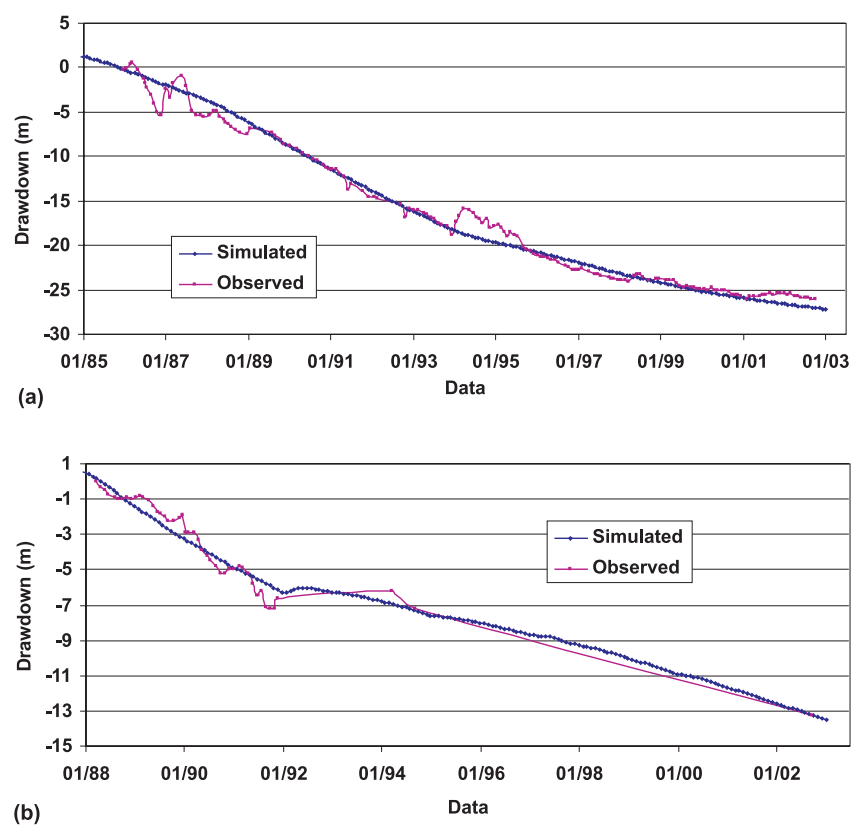

Figure 9. (a) Comparison between observed and simulated drawdowns (CD1132), (calibration period 1985-95 and validation period 1995-2002). (b) Comparison between observed and simulated drawdown (CD1213) (calibration period 1985-95 and validation period 1996-2002).

The transient calibration was firstly done by assigning initial values of the specific yield to the model layer. These values are taken from previous studies. Then, the initial values of the specific yield were changed several times by performing several computer runs until acceptable matches were obtained between the observed and simulated water levels drawdown. The range of the resulted specific yield after the final calibration of the transient state is found to be varying from 0.0001 to 0.15 .

Figure $9(\mathrm{a}-\mathrm{b})$ shows the comparison between observed and calculated drawdown in the observation wells where the drawdown is highly affected mainly by the groundwater withdrawals and slightly by the natural recharge variation resulting from rainfall fluctuation. It can be seen that in general, there is good agreement between the observed and simulated drawdown.

\section{Model verification and prediction}

Model validation is in reality an extension of the calibration process. Its purpose is to assure that the calibrated model properly assesses all the variables and conditions which can affect model results. While there are several approaches to validate a model, perhaps the most effective procedure is to use only a portion of the available record of observed values for calibration. Once the final parameter values are developed through calibration, simulation is performed for the remaining period of observed values and goodness-of-fit between recorded and simulated values is reassessed. This type of split-sample calibration/validation procedure is commonly used, and recommended, for many groundwater flow modeling studies. Model credibility is based on the ability of a single set of parameters to represent the entire range of observed data. If a single parameter set can reasonably represent a wide range of events, then this is a form of validation (Donigian 2003).

The abstraction rates from 1996-2002 were used for model validation. Reasonable agreement between the observed and simulated drawdown in the observation wells was obtained as is evident from figure $9(\mathrm{a}-\mathrm{b})$.

After obtaining the calibrated parameters, the model was run to calculate the groundwater balance for year 2002. The results are direct recharge $18.6 \times 10^{6} \mathrm{~m}^{3}$, inflow $16.5 \times 10^{6} \mathrm{~m}^{3}$, spring discharge $5.6 \times 10^{6} \mathrm{~m}^{3}$, well discharge $57.9 \times 10^{6} \mathrm{~m}^{3}$, and outflow $15.9 \times 10^{6} \mathrm{~m}^{3}$. So the overall inflow to the system is $35.1 \times 10^{6} \mathrm{~m}^{3}$, and the overall outflow is $79.4 \times 10^{6} \mathrm{~m}^{3}$. It means that the deficit is about $44.3 \times 10^{6} \mathrm{~m}^{3}$ that are compensated from the storage of the aquifer.

Four different scenarios were considered to predict the drawdown for the B2/A7 aquifer of the Mujib basin during the period 2003-2030. These scenarios are explained below:

\subsection{Scenario 1: No reduction of current withdrawal rate, i.e., $57.9 \times 10^{6} \mathrm{~m}^{3} /$ year}

In this scenario, it is assumed that the pumping rates of year 2002 are constant for the next 8,18 , and 28 years corresponding to years 2010, 2020 and 2030. The maximum drawdowns were concentrated in the well field areas, where they reached about 71.5, 90.3 and $104.9 \mathrm{~m}$ in the years 2010, 2020 and 2030 respectively in Siwaqa wells field area near Siwaqa village. The location of Siwaqa village is shown in figure 3 . 
Table 1. Maximum drawdown values $(m)$ and their location in years 2010, 2020 and 2030 under the four scenarios.

\begin{tabular}{ccccc}
\hline Year & Scenario 1 & Scenario 2 & Scenario 3 & Scenario 4 \\
\hline 2010 & 71.5 & 48.9 & 93.6 & 71.6 \\
2020 & 90.3 & 48.8 & 109.4 & 91.2 \\
2030 & 104.9 & 51.1 & 111.7 & Dry cell $(>105)$ \\
Location & Siwaqa wells field & Siwaqa wells field & Sultani wells field & Siwaqa wells field \\
\hline
\end{tabular}

\subsection{Scenario 2: $50 \%$ reduction of the} withdrawal rate or $28.9 \times 10^{6} \mathrm{~m}^{3} /$ year

The present abstraction rates of about $57.9 \times 10^{6} \mathrm{~m}^{3} /$ year will be reduced by $50 \%$ to $28.9 \times 10^{6} \mathrm{~m}^{3} /$ year. The maximum drawdowns were decreased and also recorded in Siwaqa wells field where they reached about 48.9, 48.8, and $51.1 \mathrm{~m}$ in the years 2010, 2020 and 2030, respectively. In this scenario it can be noticed that there are some kind of recovery in water drawdown in the early period and then some kind of stability in drawdown. So the abstraction rate of $29 \times 10^{6} \mathrm{~m}^{3}$ could be considered as the safe yield with this current pumping distribution. Referring to the abstraction rates before 1990 which was around $30 \times 10^{6} \mathrm{~m}^{3}$, drawdowns in the observation wells were very small.

\subsection{Scenario 3: 50\% increased of current withdrawal rate or $86.8 \times 10^{6} \mathrm{~m}^{3} /$ year}

In this scenario, the current abstraction rate is increased by $50 \%$. This increase could be acceptable theoretically, but in reality with the same well distribution, it is difficult to pump this quantity of water as wells capacity could not increase easily. In contrast wells capacity will be reduced as drawdown is increased. The maximum drawdown is about 93.6, 109.4 and $111.7 \mathrm{~m}$ in the years 2010, 2020 and 2030, respectively in Sultani wells field near Sultani village. Also dry cells (depleted cells) start to appear in year 2005 until it reaches 9 dry cells in year 2030 at Siwaqa, Qatrana, Sultani, and Karak wells field. Actually, under this scenario the north part of Mujib basin will be depleted by year 2030 .

\subsection{Scenario 4: $50 \%$ reduction of recharge rate or $10.2 \times 10^{6} \mathrm{~m}^{3} /$ year}

In this scenario, it is assumed that the pumping rates of year 2002 are constant but natural recharge rate is decreased by $50 \%$. With reducing the recharge amount the maximum drawdown compared with scenario 1 will increase from $71.5 \mathrm{~m}$ and $90.3 \mathrm{~m}$ to $71.6 \mathrm{~m}$ and $91.2 \mathrm{~m}$ in the years 2010 and
2020, respectively and from $104.9 \mathrm{~m}$ in year 2030 to dry cell in Siwaqa wells field. On average the drawdown under this scenario is increased by about $5 \mathrm{~m}$ from the first scenario. Table 1 shows a summary of the estimated maximum drawdown values and their locations (well field area) in years 2010, 2020 and 2030 for the above four scenarios.

\section{Summary and conclusion}

Processing Modflow version 5.0 (PM5) is used in this study to simulate the groundwater flow for the B2/A7 aquifer system in Mujib basin for both steady and transient conditions, to forecast the future changes that occurred under different stresses and to investigate different scenarios of artificial groundwater recharge to evaluate their effect on the water table. Model calibration for steady state condition shows very good agreement between observed and simulated initial water level contour. Transient state calibration also shows good agreement and it was verified by using drawdown data for the period 1996 to 2002. Agreement of the validation period was less than the calibration period but it gives also good and acceptable agreement for most observation wells.

Results of the calibrated flow model (steady and transient states) indicate that the horizontal hydraulic conductivity of the B2/A7 aquifer system in Mujib basin ranges between 0.001 and $40 \mathrm{~m} / \mathrm{d}$. The calibrated specific yield values range between 0.0001 and 0.15 . The water balance of the model for steady state conditions is as follows: the total annual direct recharge to the B2/A7 aquifer system is $20.4 \times 10^{6} \mathrm{~m}^{3}$; the total annual inflow (base flow) is $13.0 \times 10^{6} \mathrm{~m}^{3}$; springs discharge are $15.3 \times 10^{6} \mathrm{~m}^{3} /$ year; and total annual outflow is $18.7 \times 10^{6} \mathrm{~m}^{3}$.

Four scenarios have been considered to predict aquifer responses under different conditions of abstractions. According to the same current withdrawal rate $\left(57.9 \times 10^{6} \mathrm{~m}^{3} /\right.$ year $)$, the maximum drawdown will reach about $71.5 \mathrm{~m}, 90.3 \mathrm{~m}$ and $104.9 \mathrm{~m}$ in the years 2010, 2020 and 2030, respectively in Siwaqa wells field area. With reducing the abstraction rates by $50 \%$ of current withdrawal 
rate $\left(28.9 \times 10^{6} \mathrm{~m}^{3} /\right.$ year $)$, the maximum drawdown will reach about $48.9 \mathrm{~m}, 48.8 \mathrm{~m}$, and $51.1 \mathrm{~m}$ in the years 2010, 2020 and 2030, respectively. With increasing the abstraction rates by $50 \%$ of current withdrawal rate $\left(86.8 \times 10^{6} \mathrm{~m}^{3} /\right.$ year $)$, the maximum drawdown will reach about $93.6 \mathrm{~m}, 109.4 \mathrm{~m}$ and $111.7 \mathrm{~m}$ in the years 2010, 2020 and 2030 respectively in Sultani wells field area. Also dry areas start to appear in year 2005. With reducing the recharge rate by $50 \%$ of the average annual recharge rate $\left(10.2 \times 10^{6} \mathrm{~m}^{3} /\right.$ year $)$ and fixing the current withdrawal rate $\left(57.9 \times 10^{6} \mathrm{~m}^{3} /\right.$ year $)$, the maximum drawdown will reach about $71.6 \mathrm{~m}$ and $91.2 \mathrm{~m}$ in the years 2010 and 2020, respectively and more than $105 \mathrm{~m}$ in year 2030 in Siwaqa wells field area.

\section{Acknowledgements}

This work was supported by the Jordan University of Science and Technology as an assistantship for the second author in his M Sc. thesis. The authors wish to thank the anonymous reviewers for their suggestions and critical comments.

\section{References}

BGR/CWAJ 1987 El Lajjun Oilshale Feasibility Study Phase I, Possibilities of and constraints to groundwater development for the water supply of the envisaged oilshale processing plant, Final Report, Amman-Jordan.

Chiang W H and Kinzelbach W 1998 Processing Modflow, a simulation system for modeling groundwater flow and pollution; version 5, Hamburg, Zurich.

Donigian A S 2003 Watershed model calibration and validation: the HSPF Experience; AQUA TERRA Consultants.

JICA/WAJ 1987 Hydrologeological and water use study of the Mujib watershed; Final Report, Appendix (I), Amman-Jordan.

National Water Master Plan, Groundwater Resources; Volume VI, Ministry of Water and Irrigation, Amman, Jordan, 2001.

Tompson A F, Carle F S, Rosenberg D N and Maxwell M R 1999 Analysis of groundwater migration from artificial recharge in a large urban aquifer: A simulation perspective; Water Resour. Res. 35(10) 2981-2999. 